\title{
Erratum
}

\section{Mapping Senufo: Reframing \\ Questions, Reevaluating Sources, and Reimagining a Digital Monograph - ERRATUM}

\author{
Susan Elizabeth Gagliardi, Constantine Petridis
}

https://doi.org/10.1017/hia.2021.5, published by Cambridge University Press, 11 June 2021

In the original publication of this article, preliminary versions of Figures 5 through 9, containing watermarks from the rights-holder, were mistakenly used. ${ }^{1}$ The article authors confirm that they did obtain appropriate permission to reproduce these images, and received non-watermarked copies of the figures that should have appeared in the article.

The correct, final versions of these figures appear below. The publisher and editors apologize for this error.

\section{Reference}

Gagliardi, Susan Elizabeth, and Constantine Petridis, "Mapping Senufo: Reframing Questions, Reevaluating Sources, and Reimagining a Digital Monograph,” History in Africa (2021), 1-45. https://doi.org/10.1017/hia.2021.5

History in Africa, Volume 48 (2021), pp. 429-434

1 Susan Elizabeth Gagliardi and Constantine Petridis, "Mapping Senufo: Reframing Questions, Reevaluating Sources, and Reimagining a Digital Monograph,” History in Africa (2021), 1-45. https:/ / doi.org/10.1017/hia.2021.5

(C) The Author(s), 2021. Published by Cambridge University Press on behalf of the African Studies Association doi:10.1017/hia.2021.9 
Figure 5. Illustration of a wooden staff with "Papara. Diulla [Jula] in area of Furru [possibly Fourou, Mali]" written in an annotation. Ink drawing on paper possibly by Reinhard Hugershoff, $12.7 \times 16.8 \mathrm{~cm}$. Frobenius-Institut für kulturanthropologische Forschung an der Goethe-Universität, Frankfurt am Main, KBA 10416.
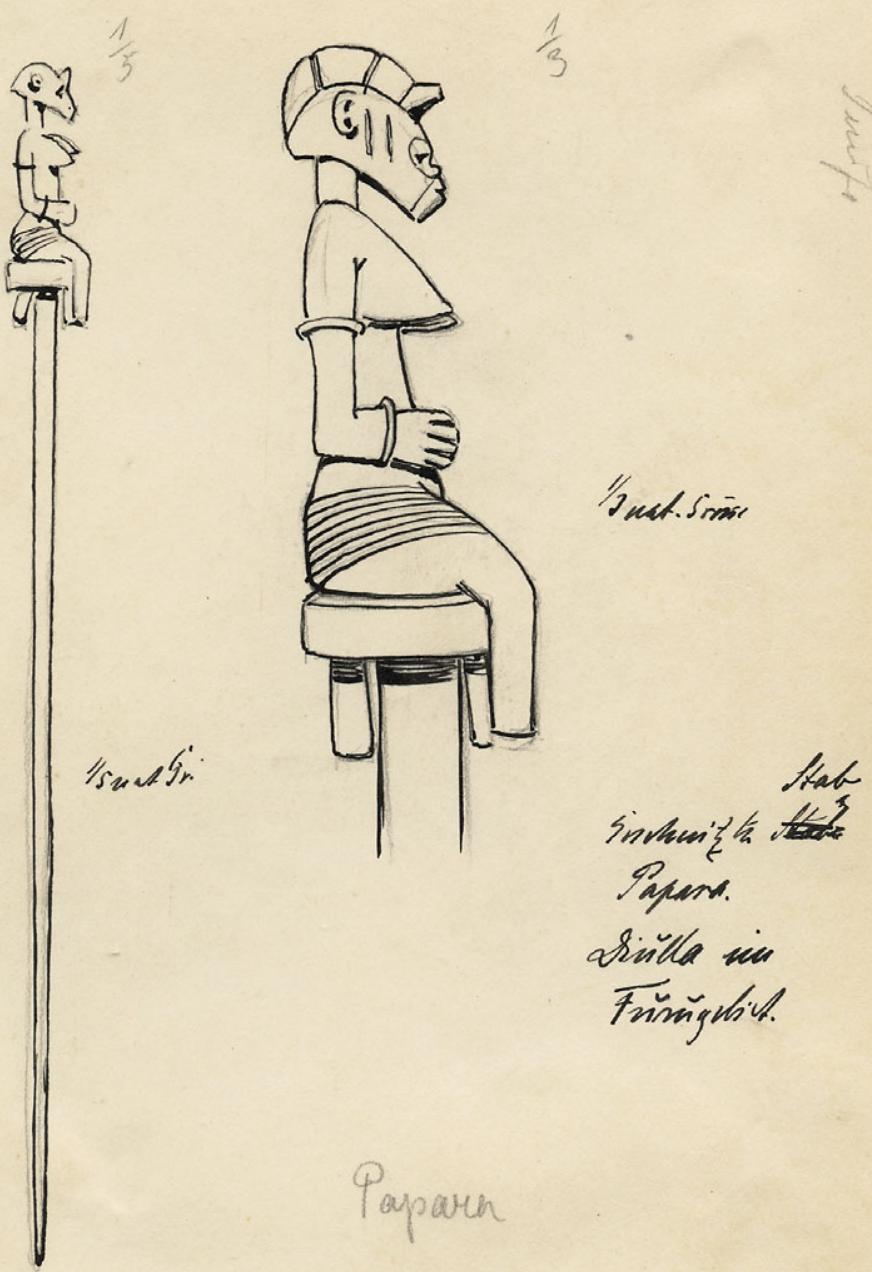

Frisnightivl. 
Figure 6. Illustration of a lidded container with annotations that read "Carved paint box of the Senufo in 1/5 of actual size. Insert cover" and "Papara - old Diulla settlement." Ink drawing on paper possibly by Leo Frobenius; $7.7 \times$ $12.7 \mathrm{~cm}$. Frobenius-Institut für kulturanthropologische Forschung an der Goethe-Universität, Frankfurt am Main, KBA 04237.
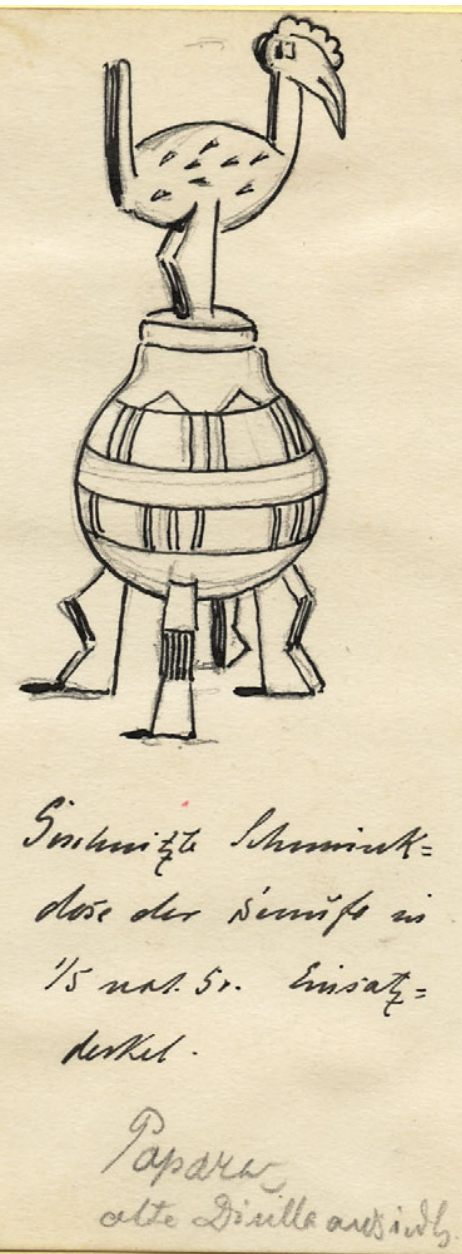
Figure 7. Illustration of a helmet mask with an annotation that reads "Mask of Komma [probably Komo] of the Senufo, Pig's Head." Ink drawing on paper by an unidentified artist; $12.7 \times 16.7 \mathrm{~cm}$. Frobenius-Institut für kulturanthropologische Forschung an der Goethe-Universität, Frankfurt am Main, KBA 10183.
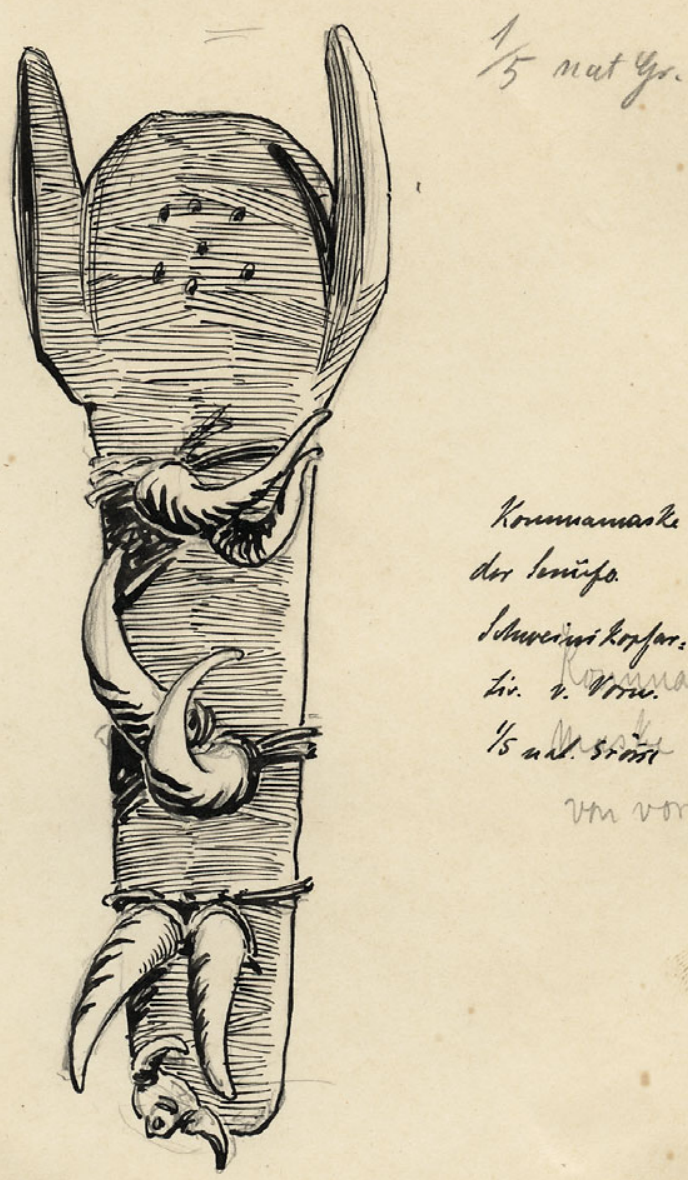
Figure 8. "Konohütte zu Kadjoro [Kono Hut of Kadjoro]," shown at 2.5 meters in height and classified as Senufo in the Frobenius-Institut database. Ink drawing on paper by Reinhard Hugershoff, dated probably 1908; $21.5 \times 15 \mathrm{~cm}$. Frobenius-Institut für kulturanthropologische Forschung an der GoetheUniversität, Frankfurt am Main, EBA-B 00232.

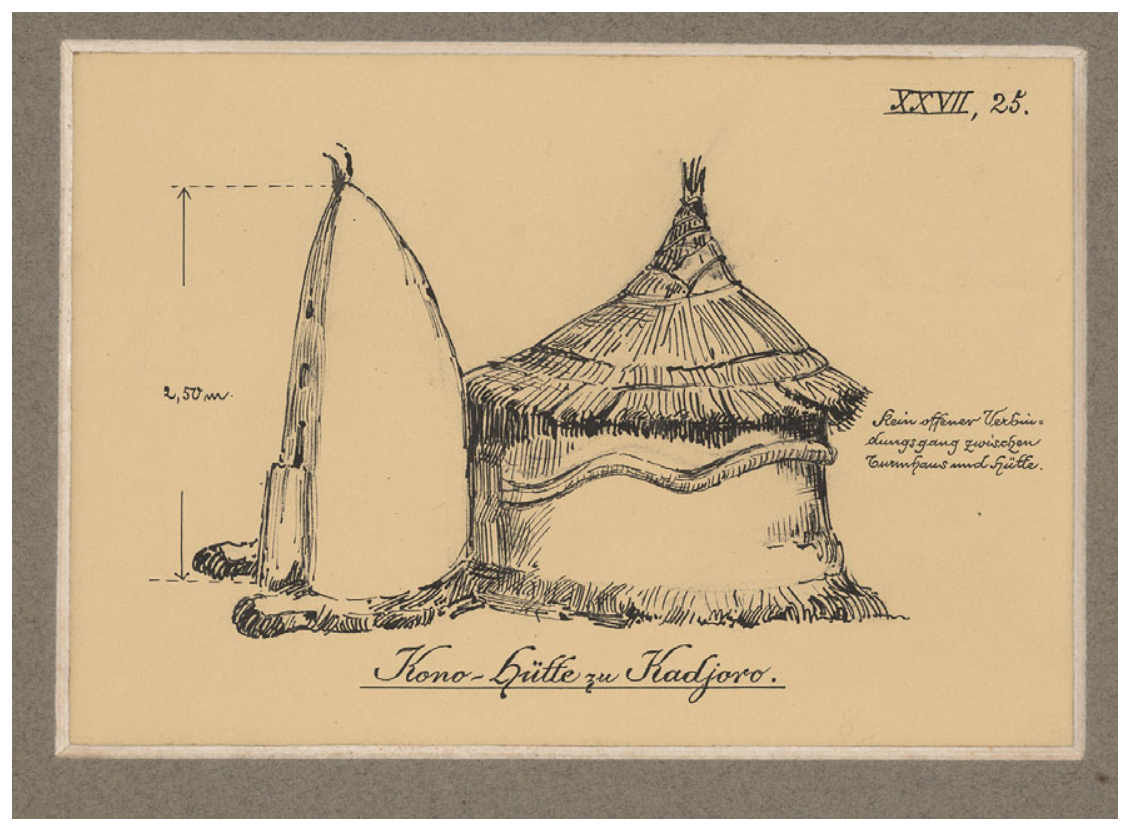


Figure 9. "Kono zu Lubugule [Kono of Lobougoula]," described as 3 meters in diameter and classified as Senufo in the Frobenius-Institut database. Ink drawing on paper by Reinhard Hugershoff, dated probably 1908; $21.5 \times 15 \mathrm{~cm}$. Frobenius-Institut für kulturanthropologische Forschung an der GoetheUniversität, Frankfurt am Main, EBA-B 00233.

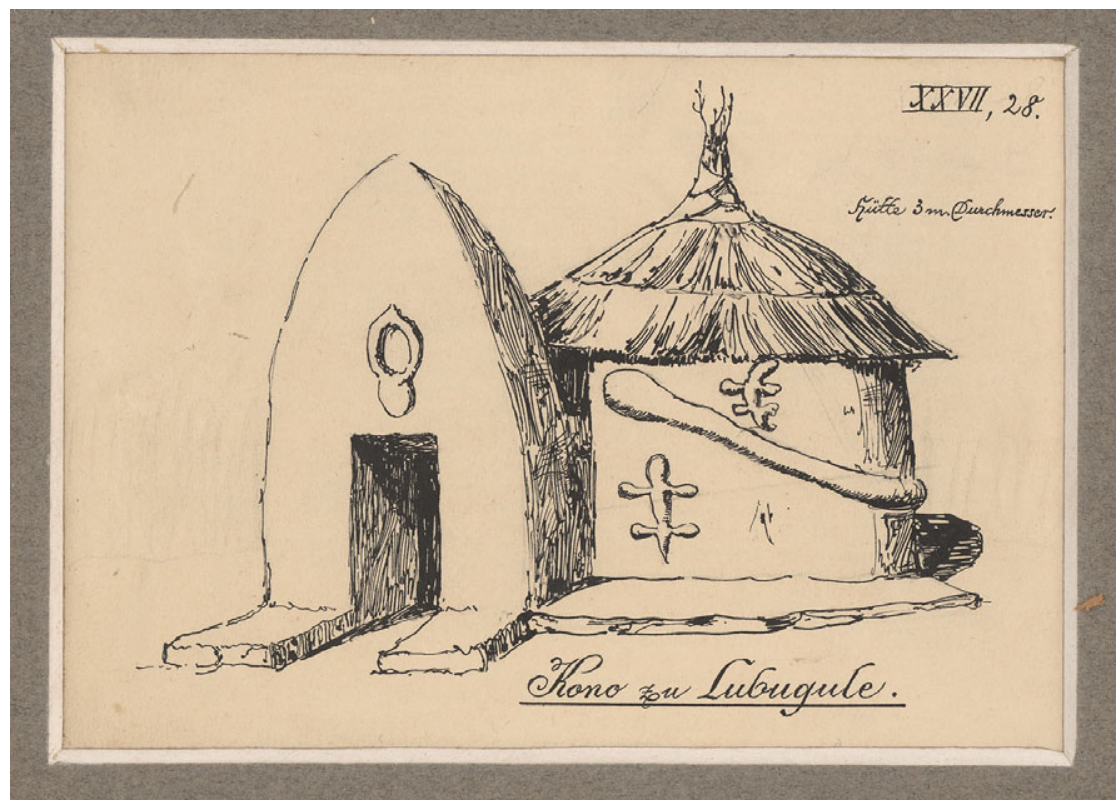

